англоязычных жаргонизмов проявляется: в способе передачи слова; в собственно словообразовании; в чередовании ударных слогов.

Вариантные формы англоязычных жаргонизмов обусловлены территориальной и социальной обусловленностью, в некоторых случаях - индивидуальным выбором. Временная вариативность особенно проявляется в применении новых понятий и реалий в сферах: «культура и развлечения», «одежда», «еда, напитки».

Проведенное исследование подтверждает тот факт, что наиболее восприимчивыми к заимствованиям являются лексико-семантические группы, которые обслуживают наиболее динамичные сферы жизнедеятельности в среде студенческой молодежи, где часто возникает потребность заполнения лексико-семантических пробелов, номинации возникающих социальных явлений и понятий. Активизация процесса заимствования английской лексики, как показывают наблюдения, обусловлена не только социально-экономическими изменениями, интенсификацией культурных и языковых контактов, но и ценностными ориентациями, формирующимися в среде студенческой молодежи, стремлением приобщиться к передовой культуре, престижностью билингвизма.

Комплекс лингвокультурологических аспектов функционирования английского языка в среде студенческой молодежи, формируя языковое сознание нового поколения, находит отражение в их языковом поведении. Молодежь наиболее чутко реагирует на все изменения в обществе, в том числе языковые. Она с большей готовностью и динамичностью по сравнению с другими возрастными группами включает в свою речь иноязычные элементы, что, в частности, ярко проявляется в составе лексики молодежного жаргона.

При отсутствии или недостаточности непосредственных контактов на английском языке билингвиальное сознание личности проявляется в употреблении ею элементов английского языка: разного рода заимствований и англоязычных вкраплений. На характер отбора и использования этих элементов влияет прежде всего фактор принадлежности личности к той или иной малой социальной группе, обладающей общим коммуникативным опытом и, соответственно, использующей в значительной степени общие языковые средства. В конечном счете выбор остается за отдельной личностью. Это сочетание и этот выбор определяют языковое своеобразие и оригинальность взаимодействия и билингвального общения в молодежной среде.

$$
* * *
$$

1. Елисеева, Е.П., Муль, И.Л. Языковая игра и компьютерный жаргон: аспекты взаимодействия // Гуманитарные исследования. - Омск, 2000. -Вып. № 5. - С. 91-93.

2. Елистратов, В.С. Арго и культура. - Изд-во МГУ. - М., 1995. - 232c.

3. Ермакова, Е.В. Жаргонизмы в речи современного подростка // Молодая филология 2002. -Пермь, 2002. - С. $133-134$

4. Ермакова, О.П. Семантические процессы в русском молодёжном жаргоне // Поэтика: Стилистика. Язык и культура. Памяти Т.Г. Винокур. - М., 1996. - С.18-23.

5. Жанэ, Д.К. О сленге в его функциональном аспекте // Неделя науки МГТИ: материалы Междунар. науч.практ. конф. - Майкоп, 2002. -Вып. № 5. -С. 83-85.

6. Морозова, О.Е. Жаргон как социопсихолингвистический и лингвокультурный феномен // Славянское слово в литературе и языке. - Архангельск, 2003. - С. 203-212.

Растворцева Д.М., Дрыгина Ю.А.

\title{
Словосложение как способ образования неологизмов в английском языке
}

Белгородский государственный национальный исследовательский университет (Россия, Белгород)

doi: 10.18411/trnio-01-2022-119

Научный руководитель: Дрыгина Ю.А.

\section{Аннотация}

В данной статье рассматривается английский язык как современный живой язык полный новых лексических единиц. Цель статьи - дать характеристику понятия 
«неологизм», рассмотреть способы образования новых слов, проанализировать способ словосложения.

Ключевые слова: неологизмы, лексические единицы, способы словообразования, словосложение.

\section{Abstract}

This article considers English as a modern living language full of new lexical units. The purpose of the article is to characterize the concept of "neologism", to consider ways of forming new words, to analyze the way of word composition.

Keywords: neologisms, lexical units, ways of word formation, compounding.

Живой язык - это язык, который используется и на котором говорят в повседневной жизни, что приводит к его обогащению новыми словами каждый день. Доказательством того, что английский язык является живым языком, кроме количества говорящих по всему миру, может быть тот факт, что Оксфордский словарь английского языка пополнился на 550 новых слов, смыслов только в январе 2020 года.

Новые лексические единицы, которые появляются в языке и называются неологизмами. Они используются во всех областях деятельности человека, если существующие слова или фразы не описывают новые явления. Данные лексические единицы формируются при помощи продуктивных словообразовательных способов. В отличие от протологизмов, недавно появившихся слов, но не получивших широкого употребления, неологизмы активно употребляются частью языка. П. Ньюмарк утверждает, что перевод неологизмов является одной из самых сложных задач для профессионального переводчика (2004).

Существует несколько способов образования неологизмов: словосложение, аффиксация, конверсия, сокращение, заимствования.

Семантически соединения, образованные словосложением, можно разделить на две категории: прозрачные и непрозрачные. Согласно Л. Бауэру: «лексема считается прозрачной, если она четко поддается анализу на составляющие ее морфы, а понимания морфов достаточно, чтобы позволить человеку интерпретировать лексему, когда она встречается в контексте» (Бауэр, 1983: 19). Напротив, значение непрозрачного соединения невозможно предсказать по его форме. Согласно анализу Р. Нордквиста морфосемантическую прозрачность можно разделить на 4 степени:

1. прозрачность обоих элементов соединения, например, lunchtime;

2. прозрачность главного элемента, непрозрачность второстепенного элемента, например, eyewitness;

3. прозрачность второстепенного члена, непрозрачность главного члена, например, green-house;

4. непрозрачность обоих членов соединения: deadline (2019).

C семантической точки зрения соединения можно также разделить на эндоцентрические и экзоцентрические. Согласно В. Адамсу, эндоцентрические соединения можно расценивать, как соединения, которые функционируют в целом, как его главный элемент, напримеp, blackbird, который обозначает разновидность птицы (1973).

Дж. Хладки делит соединения на:

1. формально эндоцентрические, когда соединение остается в том же классе слов, что и его главный элемент (например, stomachache: stomach - это существительное, асhе - тоже существительное);

2. семантически эндоцентрические, когда смысловое отношение соединения совпадает с его главным элементом (handbag - разновидность сумки);

3. формально экзоцентрическое, где главный элемент принадлежит к одному классу слов, а новое слово может принадлежать к другому классу (showoff существительное, но ни одна из его частей не является существительными); 
4. семантически экзоцентрический, когда составляющие элементы выражены разными частями речи, отличные от составленного слова сущностей, чем составное (scarecrow не является видом вороны (1996).

Однако экзоцентрическое соединение рассматриваются как соединения, в которых нельзя обозначить главный компонент, и значение этого слова сложнее понять из его составных частей.

Дополнительно слова или элементы, которые использовались для словосложения, можно разделить на подчиненные и равноправные. В равноправных соединениях нет зависимых, все равны (например, maid-servant), в то время как в подчиненных соединениях один компонент (обычно первый) работает как модификатор, выполняет функцию уточнения для главного элемента.

Подчинённые соединения можно разделить на функциональные, смысловые и формальные. Функциональная классификация сравнивает отношения между составными частями и элементами предложения (girlfriend состоит из субъекта и дополнения). Смысловая или семантическая классификация касается включения составных частей; они могут использоваться для выражения цели (put-outer), времени (day-drinking), места (mountain-snow), сравнения (pitch-black). Формальная классификация различает соединения в соответствии с их классом слов (Хладки, 1996).

Соединения также классифицируются по их словесному происхождению. Сочетание существительное + существительное (bedroom) является самой большой группой в этой классификаций. Помимо этого, существует множество других комбинаций составных слов, таких как: существительное + глагол (haircut), существительное + предлог (passer-by), глагол + существительное (driving license), глагол + наречие (lookout), прилагательное + глагол (drycleanin), прилагательное + существительное (supermarket).

Исходя из выше сказанного, словосложение можно назвать одним из самых продуктивных способов образования новых слов в современном английском языке.

$$
* * *
$$

1. Newmark, P. A textbook of translation. Harlow: Pearson Education Limited. Harlow: Pearson Education Limited. 2004.

2. Bauer, L. English word-formation. Cambridge: Cambridge University Press. 1983. C - 19.

3. Adams, V. An introduction to modern English word-formation. London: Longman. 1983. C - 34.

4. Nordquist, R. What is semantic transparency in English? Retrieved from https://www.thoughtco.com/semantictransparency-1691939 2019.

5. Hladký J., \& Růžička M. A functional onomatology of English. Brno: Masarykova univerzita. 1996.

\section{Рыжов C.A. \\ Феномен звездности (известности) с позиций фреймового подхода}

Волгоградский государственный университет (Россия, Волгоград)

doi: 10.18411/trnio-01-2022-120

\section{Аннотация}

В статье рассматривается феномен звездности (известности) на материале русскоязычных текстов СМИ. Проанализированы результаты уже имеющихся исследований в данной области. Дается определение феномена звездности (известности) и описание теории фреймов. Представлены определения структурных элементов фрейма. На примерах одного из слотов представлены описание и анализ языковых средств, формирующих феномен звездности (известности).

СМИ.

Ключевые слова: фрейм, слот, терминал, лингвокультурология, звездность, тексты 